\title{
Medicīnas vēstures muzeja sākumi
}

Paula Stradiņa Medicīnas vēstures muzeja darbinieki - zinātniskais direktors Juris Salaks, galvenā speciāliste Rita Grāvere, kā arī fotogrāfs Gunārs Janaitis - kopā ar akadēmiķi Jāni Stradiņu 2013. gada oktobrī apmeklēja Paula Stradiņa Klīnisko universitātes slimnīcu, lai apskatītu vietas, kas atgādina par Paula Stradiņa šeit ierīkoto medicīnas vēstures muzeju. Virzoties soli pa solim un klausoties Jāņa Stradiņa atmiṇu stāstījumu, iztēlē atausa muzeja attīstības pirmsākumi.

\section{Pirmā ekspozīcija slimnīcas barakā}

Atskatu pagātnē J. Stradiņš sāka ar leǵendāro vārtiņu, kas kādreiz savienoja slimnīcu ar P. Stradiņa māju, pieminēšanu. Tagad uz šo vietu ved tikai celinšs, jo pašu vārtiņu vairs nav.

Savulaik tie tika bieži virināti, arī ikreiz, kad profesors Pauls Stradin̄š no savas mājas Ventspils ielā 19 gāja uz slimnīcu.

Akadēmiķim Jānim Stradiņam joprojām žēl, ka vārtiņi netika saglabāti, plānojot slimnīcas teritorijas pārveidi. Mākslinieks Indulis Ranka gan bija izstrādājis projektu, kurā iezīmēja arī mazos, sarkanos vārtiņus slimnīcas sētā. Tiem vajadzēja kḷụt par zināmu humānisma simbolu, jo gandrīz katru nakti, steidzoties uz slimnīcu, P. Stradin̦š gāja pa šo cel̦u no mājām, kas bija turpat līdzās. Diemžēl I. Rankas ideja netika realizēta - plāna īstenotāji nevēlējās vārtiņus iebūvēt baltajā standarta ķieǵeḷu sētā.

Slimnīcas teritorijā laiks dzēsis daudzus vecos un iezīmējis jaunus vaibstus. Profesors J. Stradiņš stāstīja, ka vietā, kur pašreiz atrodas autostāvvieta (Ventspils ielas pusē), reiz bija ierīkoti tenisa laukumi. 


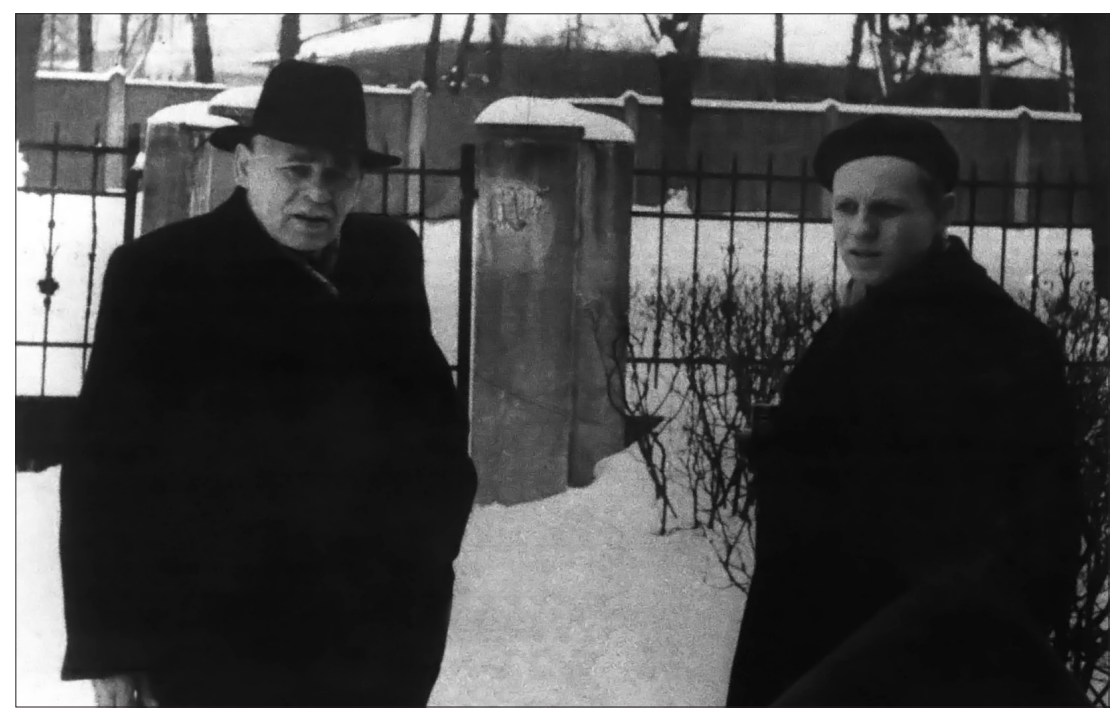

Pauls un Jānis Stradiṇi pie leǵendārajiem slimnīcas mazajiem vārtiņiem, 20. gs. 50. gadu vidus

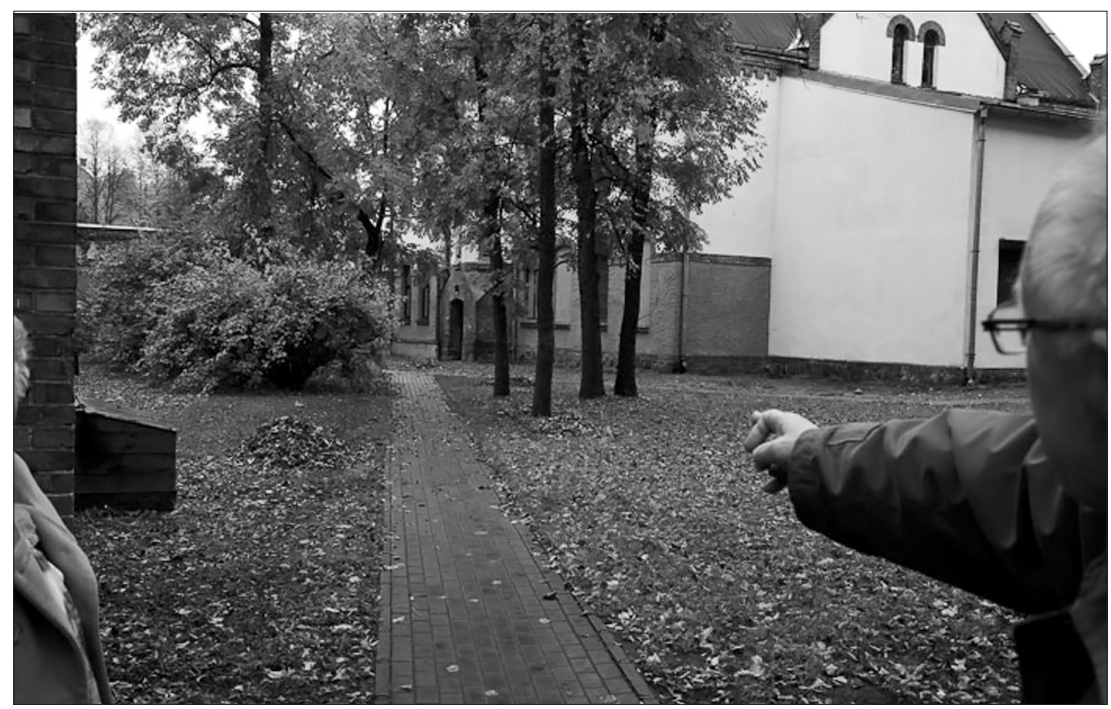

Taka no mazajiem vārtiņiem, kas savienoja slimnīcas teritoriju ar Paula Stradiṇa mājas Ventspils ielā 19 apkārtni, 2013. gads 
No 1942. līdz 1960. gadam šeit slējās arī gara koka ēka. To 1941. gadā vāciešiem bija cēluši ieslodzītie ebreji. Šās barakas 20 zālēs vēlāk, no 1945. gada, tika iekārtots medicīnas vēstures muzejs. Vācu laikā barakā atradās vācu zaldātu bibliotēka un atutošanas telpas. Bibliotēkas grāmatas J. Stradiṇa tēvs saglabāja. Starp izdevumiem bija arī populārzinātniska literatūra, kā jau zaldātiem. Pēc muzeja ekspozīcijas pārcelšanas uz tagadējo mājvietu Antonijas ielā barakas ēka kādu laiku stāvēja tukša. Vēlāk šo celtni nojauca.

Viens no profesora P. Stradina skolniekiem - Eduards Smiltens - savās atmin̄ās visai spilgti ieskicē muzeja veidošanās laiku: "Jau pirms 1940. gada profesors P. Stradiņš sāka vākt medicinnas vēstures eksponātus. Varbūt tas notika vēl krietni agrāk. Mēs, studenti - klīnikas volontieri, to sevišksi izjutām. Iepretim P. Stradiņa mājai slimnīcas sētā bija t. s. Stradiṇa vārtiṇi. No tiem sākās ceḷšs, kas virzījās gar tenisa laukumu, kur mēs pēc grūtām operācijām spēlējām tenisu, lai “izvēdinātu plaušas” pēc ilgstošām ētera narkozēm. Un tad gadījās, ka vārtiņos noskanēja atslēgu klikšksis (profesoram Stradiņam bija patiesi varena atslēgu "bunte"), atvērās vārtiṇi, un uz celiṇa parādījās profesora salīkušais augums. Redzējām, ka profesoram ir kaut kas padusē: "Kolēǵi, vai jūs man nepalīdzēsiet pielikt šo bildi pie sienas?" Cauri bija ar tenisu."

Aiz šīs barakas, kā tālāk stāstīja J. Stradinšs, citā barakā atradās vācu zaldātu kazino, vēlāk te izvietoja slimnīcas poliklīniku, no kurienes toreiz varēja iziet uz Ventspils ielu, apmēram iepretim Pārslas ielai.

\section{Diorāmas un Holodova līnija}

Jānis Stradiṇš stāstīja, ka vecajā slimnīcas sētā - pašā, pašā stūrī -, kur bija attīrī̌sanas iekārtas, 1919. gada maijā landesvēristi apšāva ievainotos sarkanarmiešus (40 pacientus), kas veseļojās slimnīcā. Tika ierīkota tāda kā soda vieta. Tajā, lai pieminētu traǵiskos notikumus, pat gribēja uzcelt mazu memoriālu, bet iecere netika īstenota.

Pirmais slimnīcas direktors neatkarīgajā Latvijā 1919. gadā bija Oskars Voits (1866-1959), viṇš vēlāk kandidēja uz Valsts prezidenta amatu, bija arī vēstnieks Vācijā.

Rīgai tolaik daudzas slimnīcas nebija vajadzīgas. Cilvēku bija palicis tik maz, ka pietika ar 1. pilsētas un Sarkanā Krusta slimnīcu. Rīgas 2. pilsētas slimnīcu (tagad - Paula Stradiņa Klīnisko universitātes slimnīcu) līdzekḷu trūkuma dēḷ 1919. gadā slēdza uz deviņiem gadiem. 


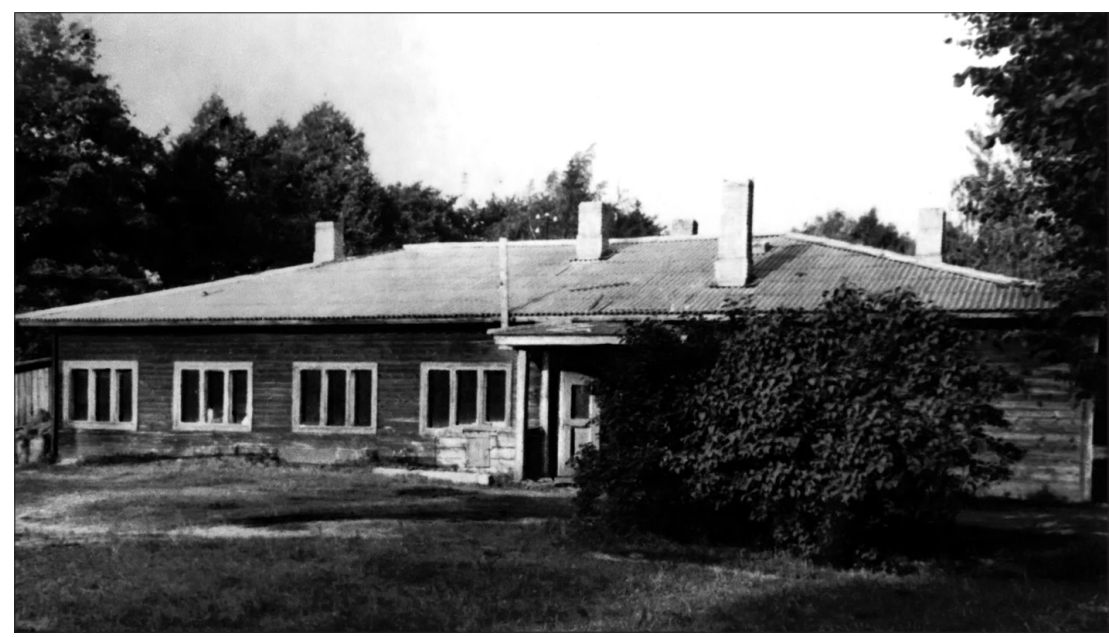

Pirmā Medicīnas vēstures muzeja ēka, vecā baraka 2. pilsētas slimnīcā, 20. gs. 50. gadi

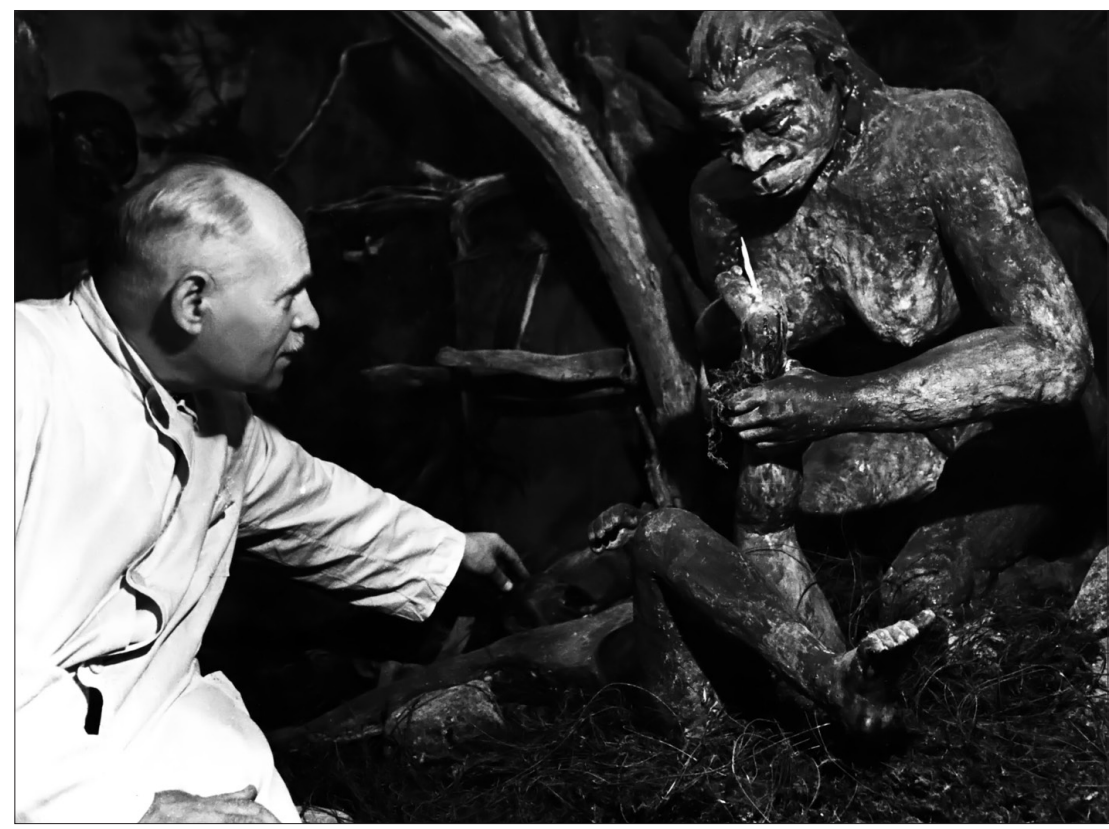

Pauls Stradiņš veido pirmo etnomedicīnas ekspozīciju, 1957. gads 
1928. gadā slimnīcā atkal uzņēma pacientus, un tajā tika izvietota Latvijas Universitātes Medicīnas fakultāte.

Pēc dažām perturbācijām gan Jēkabs Alksnis (1870-1957), gan Edvards Kalniņš (1869-1949) tika iecelti par slimnīcas direktoriem, bet viṇiem īpaši neveicās ārstniecības iestādes pārkārtošanas darbā, tāpēc 1931. gadā par direktoru iecēla tolaik jauno Paulu Stradiņu. Viņa laikāa slimnīca tiešām uzplauka - teritorijā kuploja brīnišksīgs dārzs, tika iekārtots tenisa laukums, sāka celt t. s. vecjauno ginekoloǵijas korpusu.

P. Stradiņš vadīja slimnīcu no 1931. līdz 1947. gadam, izṇemot vācu laiku, kad viņu īslaicīgi arestēja un atstādināja no amata (1941).

Slimnīcas teritorijā jāpiestāj pie skaistās gotiskā stilā celtās galvenās ēkas, kur kādreiz, vēl pirms Pirmā pasaules kara, atradās slimnīcas pārvalde, bet šodien izvietots arī P. Stradiṇa slimnīcas zinātniskais centrs. Pirms ieiet ēkā, apstājāmies pie mazām durtiṇām. Šì ieeja savulaik veda uz P. Stradiṇa, klīnikas vadītāja, kabinetu, taču mazliet vēlāk no šejienes sākās arī ceḷš uz leju, uz pagrabiem pie mākslinieka butafora Oḷǵerta Krūmiņa veidotajām diorāmām. Tās aizṇēma pagrabtelpas.

Jānis Stradiṇš stāstīja, ka muzejs vispirms atradās pagrabos, vēlāk tika izvietots arī bēniņos, kur tika veidotas O. Krūmiṇa diorāmas. Viss, kas tagad atrodas Medicīnas vēstures muzeja etnomedicīnas ekspozīcijā, tapa šeit un sākotnēji te arī tika izvietots.

Taču pagrabs ir pagrabs, ap 1955. gadu tajā pārsprāga caurules, un ekspozīcijas šamaņi “peldēja” siltā ūden̄̄, un visi metās viṇus glābt.

Paulam Stradiṇam un vina muzejam tajā laikā, 1954. gadā, aț̣āva šeit uzturēties toreizējais slimnīcas saimnieciskais direktors gruzīns Šota Palavandašvili, kurš bija ļoti veikls un izveicīgs. Tāds pat bija arī viņa pēctecis Holodovs, kurš atdalīja muzeja telpas no slimnīcas, izveidojot t. s. Holodova līniju.

Kā tas toreiz notika, savās atmin̄ās aprakstījis Eduards Smiltens: "Muzejam nebija savu telpu. Par tādām tika izmantotas arī slimnīcas garo koridoru pagrabtelpas, un jāsaka, ka šī ekspozīcija par vissenākajiem laikiem bija l̦oti efektīga - te patiesi dvesa senatne. Bija tikai viena nelaime muzejs pletās arvien plašāk pagraba garajos kanalizācijas koridoros, un pret to protestēja toreizējais slimnīcas administratīvais direktors Holodovs. Pēc ilgām sarunām bija noslēgts miers - uz pagraba sienas ar baltu krāsu tika novilkta vertikāle, kas nozīmēja - "tālāk, Pavel Ivanovič, nevar". Šì līnija vēl ilgi bija redzama un ieguva Holodova līnijas nosaukumu." 
Paveroties augšup uz ēkas gotiskajiem bēniņiem, var iztēloties viduslaiku pilsētu. Daudzi viesi atzinuši, ka pati telpa runā ar apmeklētāju. Šì ekspozīcija vēl šodien, tiesa gan nedaudz pārveidota, skatāma lielajā muzejā Rīgas centrā.

Savukārt vecās pārvaldes ēkas pašā augšā, ceturtajā stāvā, jau 1929. gadā tika veidots ķirurǵiskās patoloǵijas muzejs. Te bija visa sākums. Tas vēl nebija medicīnas vēstures muzejs, bet vien ķirurǵiskās patologijas muzejs, kura dzīlēs pamazām sāka veidoties medicīnas vēstures muzejs.

Akadēmiķis J. Stradiņš, vedinot iet iekšā, stāstīja, ka no gaiteņa savulaik veda kāpnes uz profesora Paula Stradiña kabinetu. Šeit mums pievienojās slimnīcas Zinātņu attīstības departamenta vadītājs, profesors Dainis Krieviņš un slimnīcas Kardioķirurğijas nodaļas vadītājs, profesors Pēteris Stradiņš.

Pēteris Stradiņš, papildinot stāstījumu, skaidroja, ka kādu laiku kabineta vietā bijusi sieviešu, tagad - ķirurgu, geērbtuve pie operāciju zāles.

Jāṇa Stradiņa bērnības atmiñās palicis, ka kādā lielā telpā, kas piekrauta ar papīriem, atradās pilna Zentas Mauriņas un Konstantina Raudives bibliotēka, kas vēlāk it kā pārnesta uz augšējiem stāviem, bet, kur tā galu galā palikusi, viņš nezināja.

Viņu nedaudz skumdina, ka Paula Stradiņa kabineta telpas ir grūti pazīt, jo tik lielā mērā tās ir pārveidotas. Tomēr profesora aura laikam saglabājusies, jo, par spīti pārbūvei, Jānim Stradiṇam vienalga ir interesanti šeit atrasties... Savukārt Pēteris Stradiņš, papildinot tēva stāstīto, atcerējās, ka viņa studiju gados šeit bijusi konferenču telpa.

1954. gadā Pauls Stradiņš vairs nekādu administratīvo amatu slimnīcā neieņēma, bet viņa autoritāte tomēr bijusi tik liela, ka muzeja ierīkošanai atdeva gan bēniņus, gan pagrabu, tiesa, līdz zināmai robežai. Šeit tad arī viņš veidoja muzeju un tajā strādāja.

Kā atzīst J. Stradiņš, muzeju iekārtot palīdzēja arī klīnikas asistenti. P. Stradiņš muzeja darbam bija piesaistījis urologu Eduardu Smiltenu (1918-1992), mazāk - ķirurgu Jāni Slaidiṇu (1916-2000), Arturu Rocēnu (1907-1988), Vladimiru Utkinu (1932-1994) un Ēvaldu Ezerieti (1913-2013). Arī jaunos mediķus viņš lika pie darba. Viņiem bija jāapgūst muzeja gudrības - jāstiklo un jāmācās arī citas praktiskas lietas. Tēvs teica, atceras J. Stradiņš, ka ķirurgam tas viss varot noderēt. 


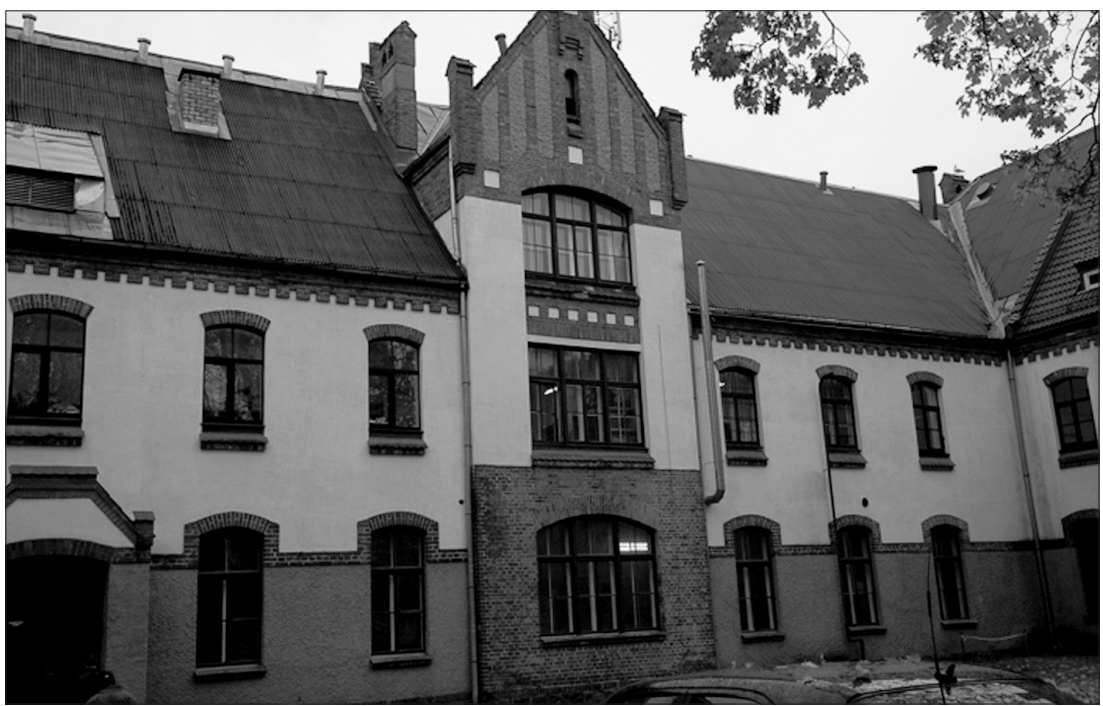

Rīgas 2. slimnīcas ēka, kuras bēniņos 20. gadsimta vidū tika izvietots Medicīnas vēstures muzejs, 2013. gads

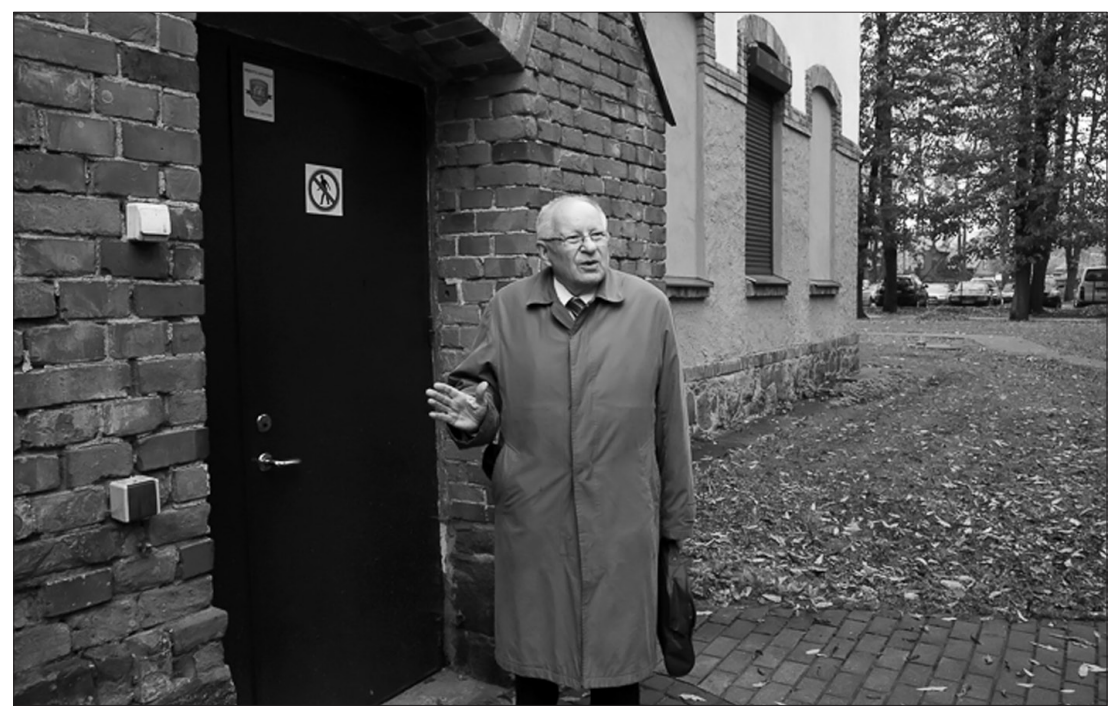

Jānis Stradiṇš pie Rīgas 2. slimnīcas ēkas, kur bēniņos savulaik atradās Medicīnas vēstures muzejs, 2013. gads 
Muzejs slimnīcā tika izvietots divās ēkās. Vecajā, jau pieminētajā barakā atradās ekspozīcijas Ķīnas, Ėgiptes un Austrumu nodaḷa, kā arī grieķu un romiešu nodaļa. Tur arī tika gleznota lielā Leo Kokles (1924-1964) glezna - dižo medicīnas korifeju kopējais portrets uz antīku celtņu un gaiši zilas dienvidu debess fona. Mākslas darbs bija iecerēts par muzeja barakas lielās zāles centrālo akcentu. Tur šad tad iegriezās arī cits ne mazāk pazīstams gleznotājs Jānis Pauḷuks (1906-1984), strādāja vairāki citi mākslinieki.

Savukārt otrā vietā - lielajā ēkā (sešstāvu namā) -, bija papildekspozīcijas telpas, kurās ievietoja diorāmas. Interesanti, ka šeit profesora galvenajam konsultantam, domubiedram un palīgam, izcilajam gleznotājam un tēlniekam Jānim Tīlbergam (1880-1972) bija iekārtota maza darbnīca, kur viņš varēja gleznot. Muzeja platība toreiz bija pat lielāka par tagadējo.

Jānis Stradiņš labi atceras to laiku. Kad viņam bija jāsauc tēvs uz brokastīm vai vakariṇām, pa stāvajām kāpnēm bija jāskrien uz augšu, uz kabinetu. Viņš neslēpa, ka pārṇem dīvaina sajūta, ieraugot šo vietu, kur nav būts ļoti sen.

\section{Paula Stradiṇa auditorija un vācu lazarete}

Tālāk ceḷš veda uz Lielo slimnīcas auditoriju, Paula Stradiņa auditoriju.

Ienākot telpā, Jānis Stradiņš atzinās, ka tā laika gaitā nemaz nav mainījusies. Tāda bijusi arī vācu laikā, pateicoties toreizējā LU rektora, profesora Mārtiņa Prīmaņa (1878-1950) ierosmei un arī vācu kara hospitāla šefārstu Vērta un Kvaziga (Quasig) pretimnākšanai, jo tolaik slimnīcā izvietojās vācu kara hospitālis. Tajā par rentgena māsu vai laboranti vācu "darba dienestam" tika pakḷauta un strādāja arī viņa māsa Maija. Visus civilos pacientus no šīm telpām izlika ārā. Toties te drīkstēja pulcēties studenti, no kuriem daudzi tolaik bija arī leǵionāri. Savukārt bērniem vācu laikā uz "lielo māju" tika ieteikts nestaigāt.

Civilie pacienti, kā atceras J. Stradiņš, tika izvietoti 38. barakā, kas nebija saistīta ar muzeju, un vēl dažās citās ēkās.

Vācu laikā Paulu Stradiṇu arestēja un atstādināja no amata. Tomēr slimnīcā par medicīniskiem direktoriem palika ļoti kārtīgi latviešu ārsti: ķirurgs profesors Jānis Šulcs (1885-1979) un ginekologs docents Jānis Āboliņš (1906-1994). Taču viṇi nepārzināja slimnīcu kopumā, bet tikai to daḷu, kas atradās latviešu pārziṇā, galvenokārt barakas. 


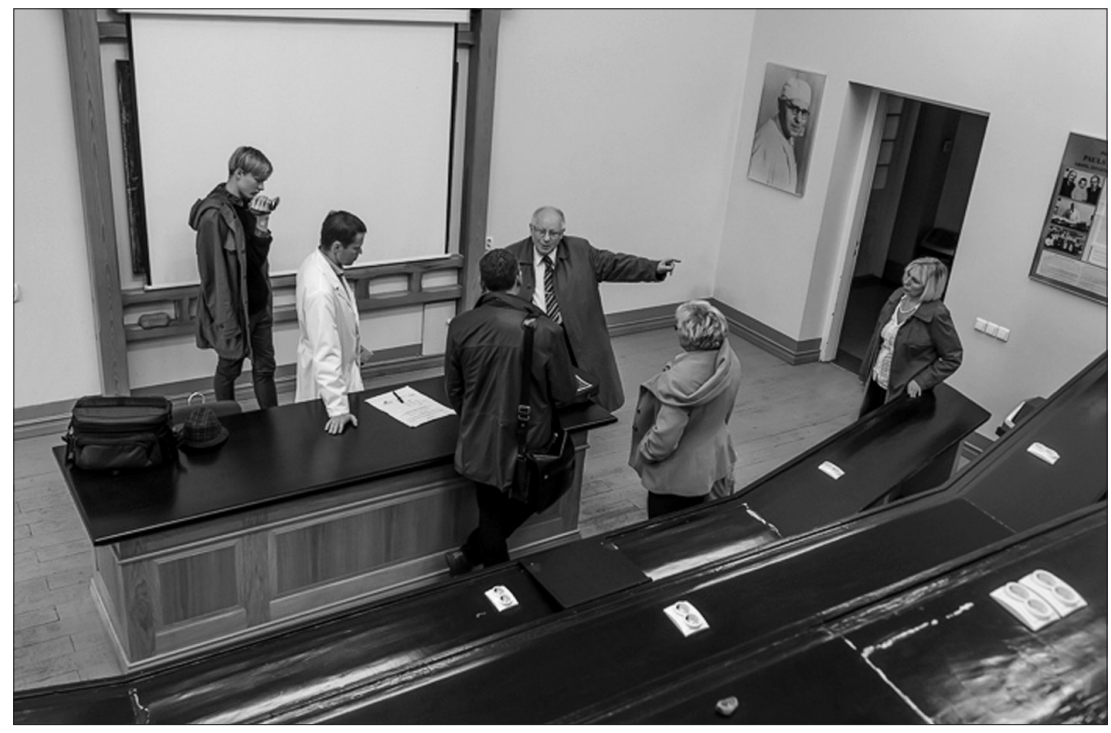

Paula Stradiña Medicīnas vēstures muzeja darbinieki klausās Jāṇa Stradiṇa (centrā) stāstījumā slimnīcas Lielajā auditorijā, 2013. gads

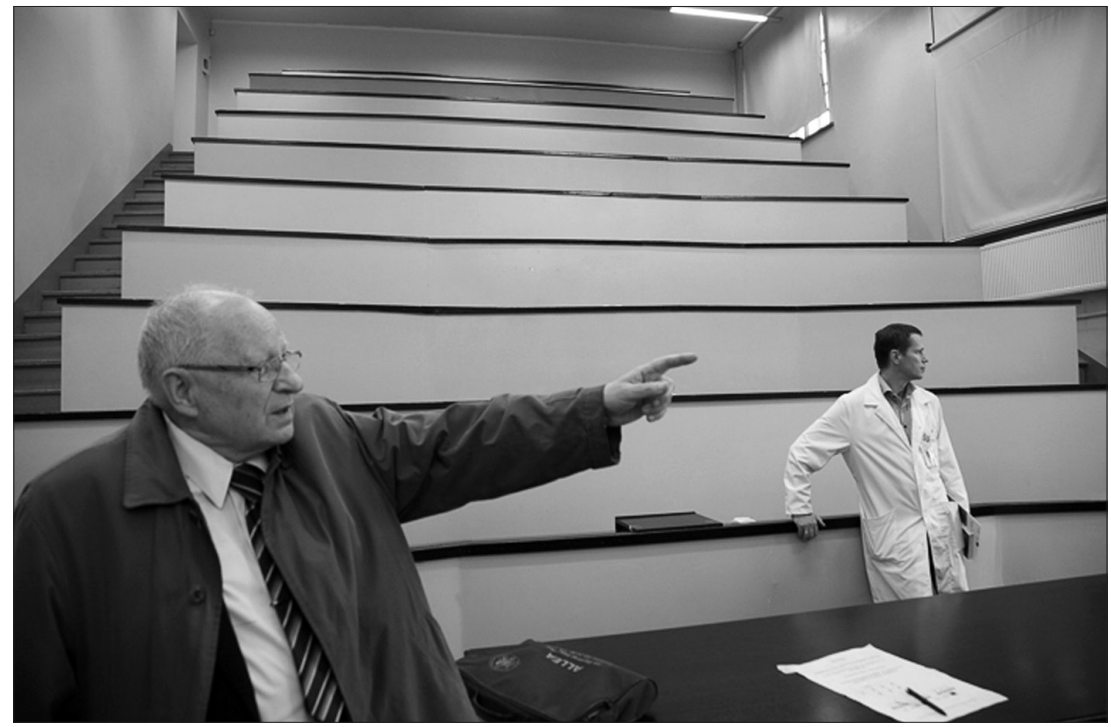

Jānis (priekšplānā) un Pēteris Stradiņi slimnīcas Lielajā auditorijā, 2013. gads 


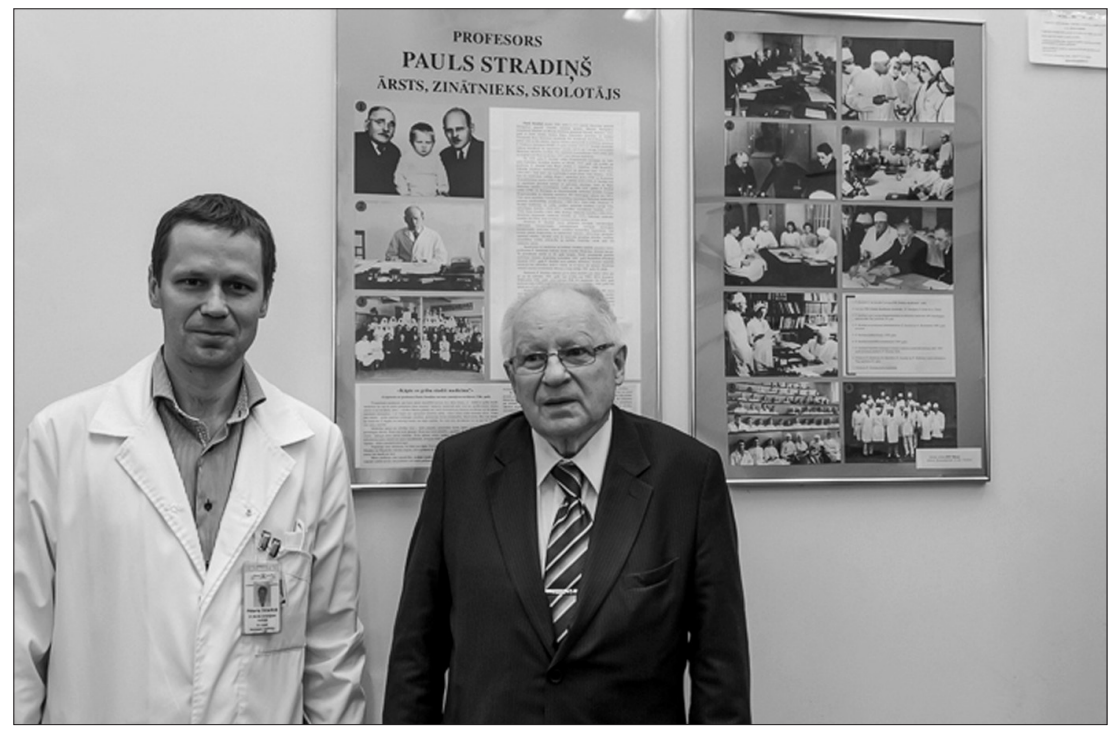

Pēteris (no kreisās) un Jānis Stradiṇi

Paula Stradiña auditorijā, 2013. gads

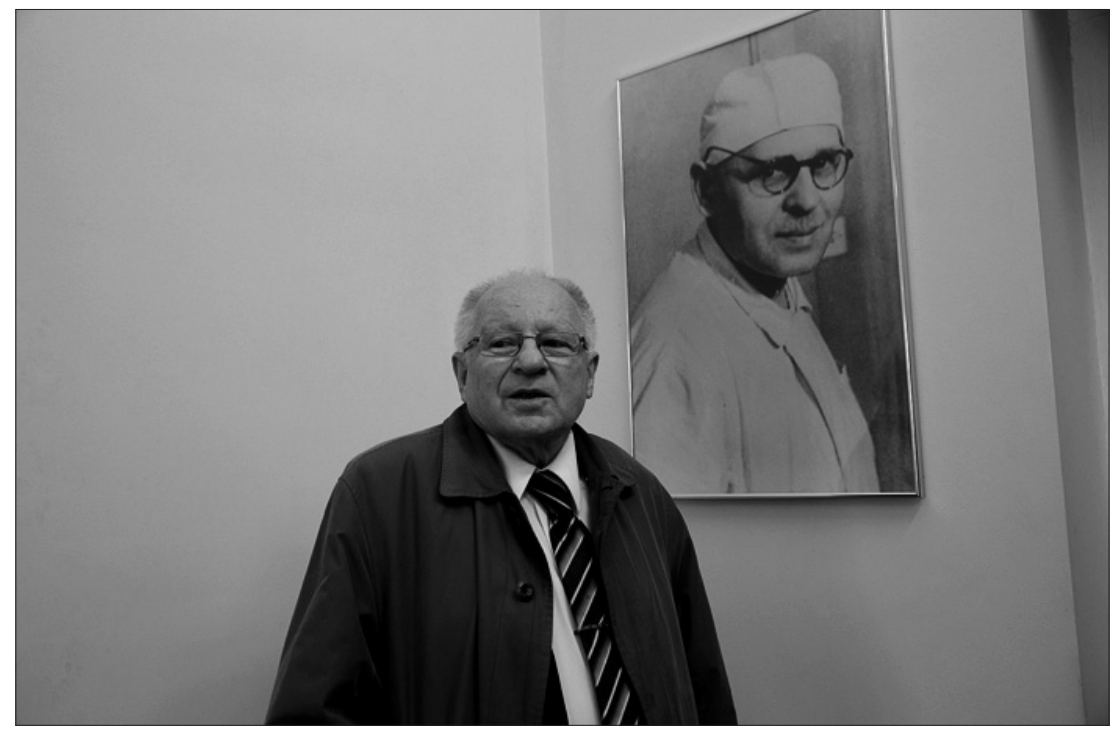

Akadēmiķis Jānis Stradiņš pie tēva portreta

Paula Stradiña auditorijā, 2013. gads 
Vācu kara lazareti toreiz vadīja jau pieminētie divi ļoti interesantie vācu kara ārsti - Kvazigs un Vērts. Abi bija labvēlīgi noskaņoti pret latviešiem. Vērts pat apprecēja latvieti un sludināja ideju, ka visi latvieši varot ieprecēties vāciešos, kas skaitījās ārieši. Tāpēc, lai tik ātrāk pārejot vāciešos, tad viss būšot kārtībā. Vērtu pašu pēc tam esot it kā notiesājuši par prethitlerisku darbību. Savukārt Kvazigs bija omulīgs, patukls vācietis no Ķelnes, viņam piederēja suns (taksis), ko aprūpēja māsa Zarinna. Tas bija viņas galvenais uzdevums - izvadāt taksi un dzīvnieku kopt. Vērts arī bija starp cilvēkiem, kas izglāba Paulu Stradiņu no gestapo priekšnieka Langes nagiem 1941. gadā. Dramatiski notikumi te ir risinājušies.

Lūk, šeit ir auditorija, kurā 1944. gada maijā, kad atzīmēja Latvijas Universitātes Medicīnas fakultātes 25 gadu jubileju, ar referātu par medicīnas uzdevumiem Latvijā uzstājās Pauls Stradiņš. Kristaps Rudzītis toreiz runāja par bazofiliem leikocītiem.

Vērpjot savu atmiṇu stāstījumu tālāk, Jānis Stradinš̌ atzina, ka šajā auditorijā Pauls Stradiņš nolasīja savu pēdējo lekciju. Šeit 1958. gada vasarā uzṇemtas arī dažas pēdējās profesora fotogrāfijas.

Auditorijā, netālu no mazām durtināam, ir nofotografēts viss klīnikas kolektīvs, kurā redzams gan ķirurgs Ēvalds Ezerietis, gan Ojārs Aleksis, gan Arturs Rocēns un medicīnas māsas.

Profesors P. Stradiņš šurp veda arī ekskursijas. Divas vai trīs dienas pirms nāves (1958. gada augustā) viņš vēl vadīja ekskursiju PSRS Zinātnuu akadēmijas tūristu grupai, kas no Bullı ciema bija atbraukusi pie viņa viesos. Saglabājusies arī fotogrāfija, kurā redzams O. Krūmiņš, kas arī vadīja ekskursiju. "Te," atzinās Jānis Stradiņš, "pat es esmu kaut kur paslēpies."

Pie auditorijas sienas redzama slavenā profesora Paula Stradiņa fotogrāfija, ko uzṇēma vēlākais profesors Jevgenijs Linārs (1920-2003). "Tā uzṇemta pie operāciju zāles, un, kā Dr. Linārs man stāstīja," teica J. Stradiņš, "tēvs bijis pēc operācijas mazliet noskaities un sanervozējies, un tad Linārs viņam teicis: "Profesor, profesor, pagriezieties!" un virzījis uz viņu fotoaparātu. Un profesors arī pagriezies un pasmaidījis. Manuprāt, tā ir visraksturīgākā profesora fotogrāfija." 


\section{Pirmās Medicīnas vēstures muzeja ekspozīcijas foajē}

Stāvu augstāk par P. Stradiņa auditoriju atrodas foajē. Savulaik, lai studenti tur nesmēķētu, foajē izstādīja ne vien mākslas darbus, bet ar̄̄ dažādus citus priekšmetus, vēlāk izveidoja arī mazu ekspozīciju. 1938. gadā trīs telpās izveidoja paša pirmā Medicīnas vēstures muzeja ekspozīciju, kas tur pastāvēja līdz 1944. gadam. Lai gan tur atradās vācu kara lazarete, studenti varēja iet apskatīties izstādītos darbus un materiālus.

1945. gada jūnijā muzeju pārvietoja uz baraku. Uz turieni pārnesa visu iekārtu, bet līdz šim aizņemto telpu atbrīvoja. Pēc kāda laika barakā muzejam kḷuva par šauru, un tad sāka apgūt vispirms lielās ēkas pagrabus, pēc tiem - lielos bēniņus.

J. Stradiņš, stāstot par medicīnas vēstures liecību krāšanu, rādīja fotoattēlu, kas ataino muzeja atklāšanu 1961. gadā jaunajās telpās Antonijas ielā 1 .

Vēlāk, izejot no galvenās ēkas, muzeja sākumu meklējumos apstājāmies pie nu jau vēsturiskā slimnīcas skursteņa.

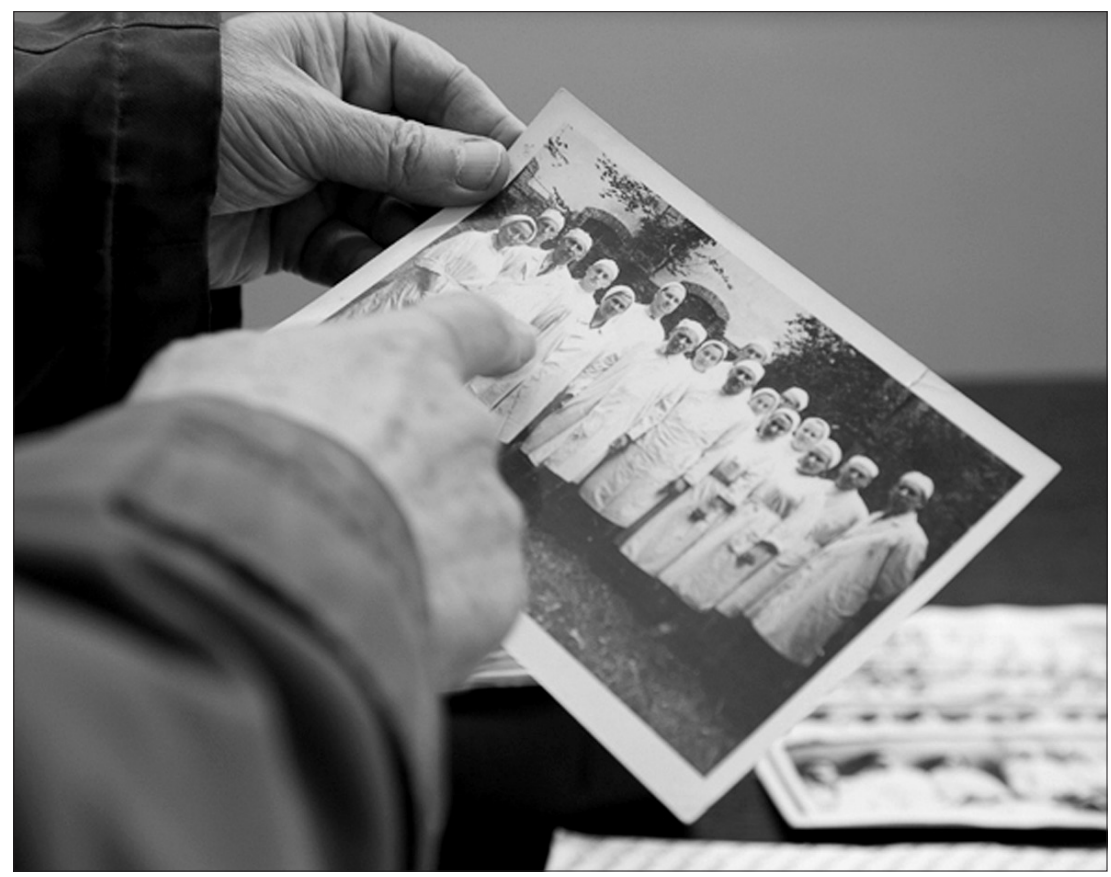

Vecās fotogrāfijas attēlo slimnīcas vēsturi 


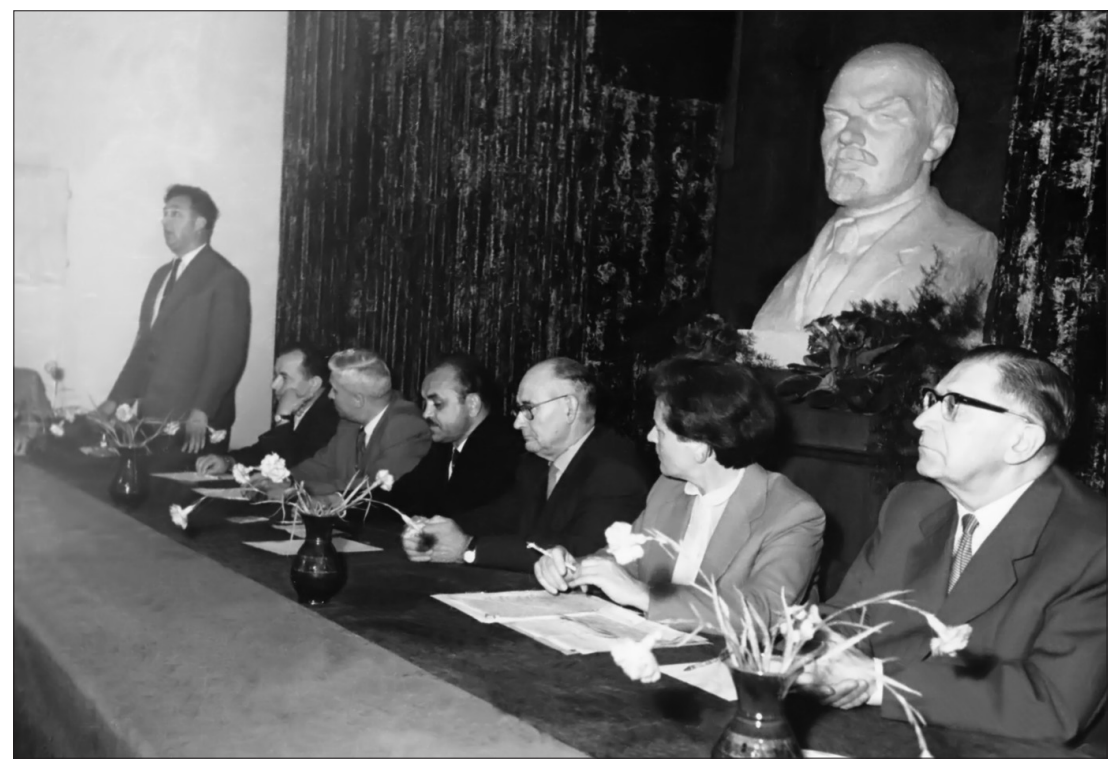

Medicīnas muzeja oficiālā atklāšana 1961. gadā. Prezidijāa (no labās) sēž profesors Aleksandrs Bieziņš, Herta Hanzena, kādreizējais veselības aizsardzības tautas komisārs, toreiz - Latvijas PSR Augstākās Padomes prezidija priekšsēdētāja vietnieks Ernests Ameriks, arī Vilhelms Kaṇeps, toreiz - veselības aizsardzības ministra vietnieks, un Ministru padomes priekšsēdētāja vietnieks Vitālijs Rubenis

\section{Kara beidzamie akordi}

Slimnīcas kurtuve, kur strādāja Datkuns, slimnīcas šoferis un reizē arī kurinātājs, ir tieši tā vieta, kur Pauls Stradiņš 1944. gada 15. oktobrī satika krievu automātistus, kas nāca iekšā slimnīcā. Nedaudzie slimnieki lielākoties bija izvietoti “jaunās mājas” otrajā stāvā (augšējie stāvi tolaik vēl nebija uzbūvēti). Pagrabos tobrīd bija paslēpušās visas slimnīcas darbinieku ǵimenes. Kad sāka degt vāciešu uzspridzinātā fabrika "Lenta", slimnīcas darbinieki un apkārtējie iedzīvotāji metās pie milzīgā ūdens baseina slimnīcas teritorijā un sastājās rindā ar spaiņiem līdz pat "Lentai". Dzīvā ķēdē padodot ūdeni, cilvēki mēǵināja dzēst liesmojošo fabriku, lai uguns nepārmestos uz slimnīcu. Tas bija aptuveni 6.-10. oktobrī, neilgi pirms vācu aiziešanas. Pašreiz te plešas milzu būvlaukums, kur ceḷ moderno slimnīcas korpusu, iepretī "vecjaunajai” mājai. 


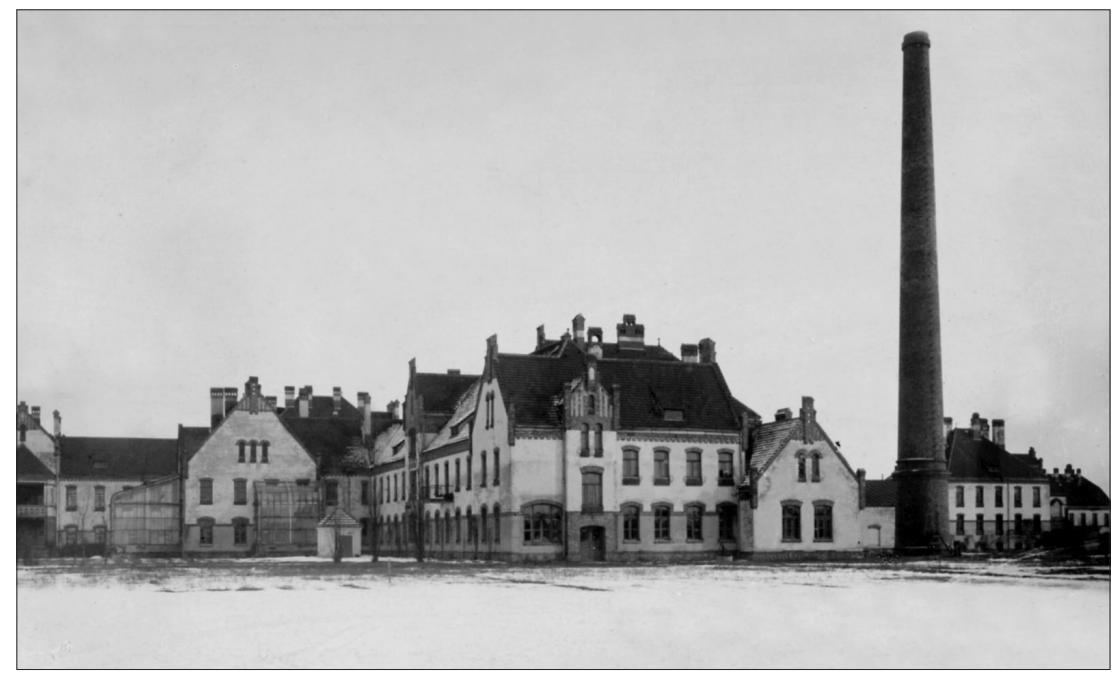

2. pilsētas slimnīca ar kurtuvi 20. gs. 30. gados

1944. gada ruden̄̄ pavisam reāli bija apdraudēta galvenā (vecā) slimnīcas èka, kuras vestibilā virs auditorijas atradās arī pati pirmā medicīnas vēstures ekspozīcija. 1944. gada 19. septembrī krievu aviācija, bombardējot arsenālu, nometa bumbas pie slimnīcas galvenās ēkas ieejas Pilsoņu ielā un arī Paula Stradina mājas dārzā. Bojājumi tika nodarīti slimnīcas ieejas vestibilam un rentgena nodaḷai, korpusa viṇā galā, tālu no medicīnas vēstures ekspozīcijām.

Bet oktobra sākumā, evakuējot lazareti, vācieši gatavojās galvenā korpusa uzspridzināšanai, mīnēšanas priekšdarbiem (jaunais korpuss bija pusuzcelts, bet vācieši tur jau veica ķirurǵiskās operācijas, tieši šī korpusa pagrabos varas pārejas dienās visi mitinājās). Slimnīcā par personāla pārzini toreiz strādāja darbīgs, loti īpatnējs cilvēks Augusts Linde, no Iršu kolonistiem, pusvācietis, kuram bija labi sakari ar slimnīcas vācu administrāciju un arī potenciālajiem spridzinātājiem. Vin̦š prata pārliecināt, lai slimnīcu nespridzina un nededzina, - tā sarunā nesen atcerējās viṇa meita Līga Strakšes kundze, kura dramatiskajās 1944. gada oktobra dienās arī pati kopā ar citiem uzturējās slimnīcas pagrabā. Šos apstākḷus labi zināja arī Pauls Stradiņš, kuru Dr. Jānis Āboliņš bija atstājis savā vietā par latviešu slimnīcas vadītāju, pašam evakuējoties uz Kurzemi. Ja slimnīcas galveno ēku uzspridzinātu, medicīnas muzeja ekspozīcijas un vērtīgās grāmatas būtu gājušas bojā, un tas Latvijas medicīnai būtu neatsverams zaudējums. 


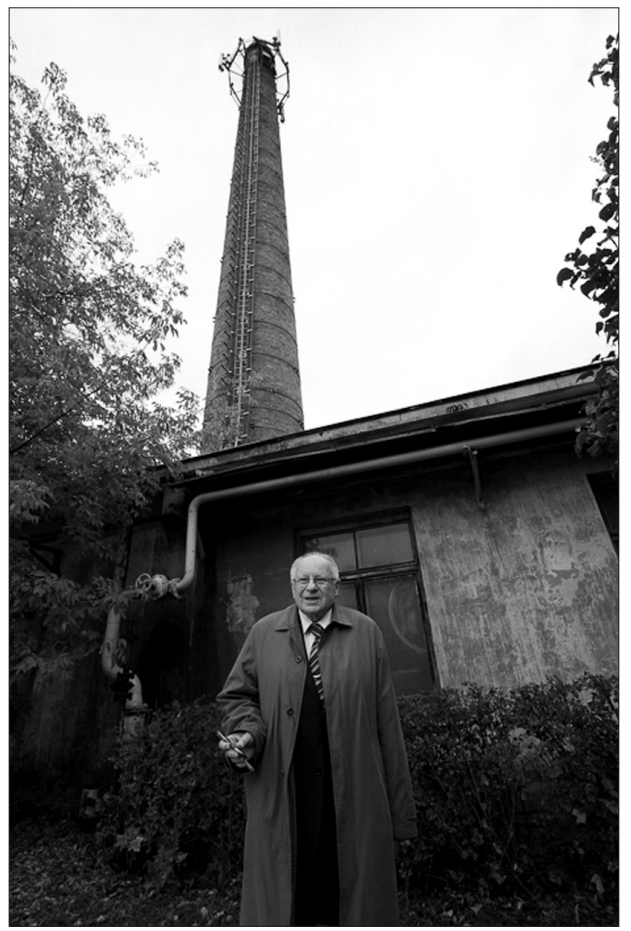

Akadēmiķis Jānis Stradiņš pie slimnīcas kurtuves 2014. gadā

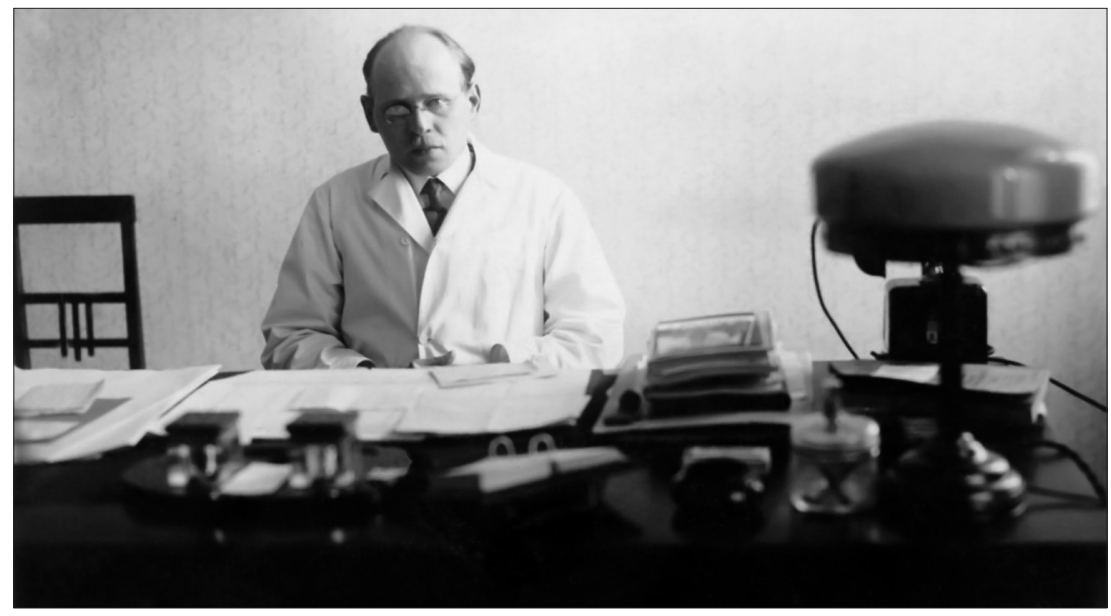

Profesors Pauls Stradiņš savā slimnīcas direktora kabinetā ap 1932. gadu 


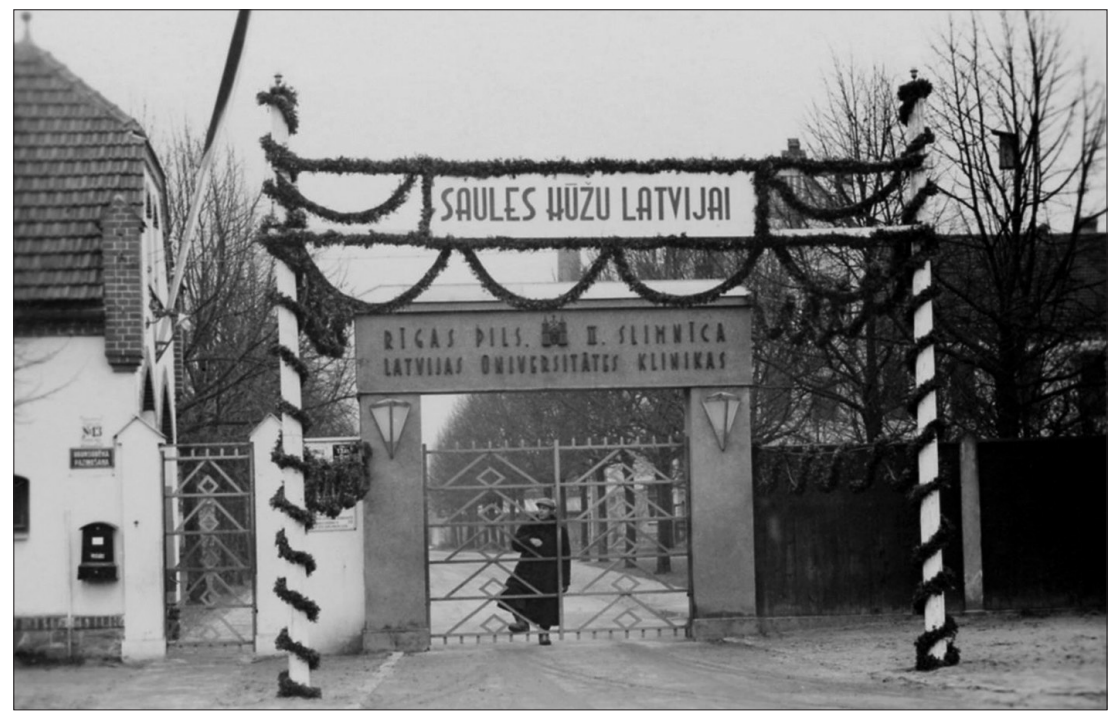

Rīgas 2. pilsētas slimnīcas ieejas vārti, 1936. gada 18. novembris

15. oktobrī Pauls Stradiņš izgāja no slimnīcas pagraba pretī padomju automātistiem, un vēsturiskā tikšanās notika pie lielā slimnīcas skursteņa. Viņš krieviski ziņoja, ka slimnīcā esot tik un tik civilo pacientu, bet militārpersonu, ievainoto vācu karavīru un vlasoviešu te neesot. Ziņojumu “pien̦ēma”, nebija nekādas vardarbības. Vienīgi vada komandieris esot palūdzis profesoru atdot pildspalvu un pulksteni, kas viņam vajadzīgi dienesta uzdevumu veikšanai. Profesors atgriezās pie pagrabā palikušajiem sveiks un vesels, bet pārbiedēts gan un nezin̄ā par turpmāko. Linde palika strādāt arī padomju laikā, viņš bija Valsts klīniskās slimnīcas kancelejas pārzinis, rakstīja slimnīcas vēstures hroniku, bet par saviem nopelniem slimnīcas ēkas glābšanā un sakariem ar vāciešiem īpaši nerunāja. Viņš atmiṇā palicis kā mazliet mīklaina, neordināra personība.

1944. gada 16. oktobrī ar veselības tautas komisāra vietnieka Mihaila Joffes rīkojumu P. Stradiṇu iecēla par slimnīcas galveno ārstu. Tālāk samērā labvēlīga varas attieksme turpinājās līdz 1946.-1947. gadam, kad P. Stradiņu sāka kritizēt, un pamazām viņam no visu institūciju vadības bija jāaiziet. Arī muzeja liktenis sarežǵījāâ, par tā tālāko gaitu līdz nonākšanai Antonijas ielā 1 sīkāk var izlasīt apjomīgajā Jāṇa Stradiņa publicējumā 
izdevuma "Acta medico-historica Rigensia" VIII sējumā. (Par situāciju slimnīcā 1944. gadā sīkāk sk. citā J. Stradiṇa rakstā "Acta medico-historica Rigensia" IV sējumā, 211.-224. 1pp.)

\section{Profesora Paula Stradiņa piemineklis}

Plašajā slimnīcas dārzā ir Paula Stradiña piemineklis. Profesors nomira 1958. gada 14. augustā. Paula Stradiņa bisti veidojusi tēlniece Aleksandra Briede, kas tolaik dzīvoja Pārdaugavā. Situācija izveidojās neparasta: pieminekḷa izstrādes konkursā uzvarēja Lea Novožeņeca un Sirgeda Krūmiņa, bet viņu veidotie meti nepatika P. Stradiņa ǵimenei, tie likās pārāk "padomiski”. Tad dakteris A. Rocēns piedāvāja pieminekḷa metu, ko bija izstrādājusi tēlniece A. Briede. Viņas vīrs (tēlnieks Jānis Briedis) bija miris 1953. gadā profesora P. Stradiņa klīnikā.

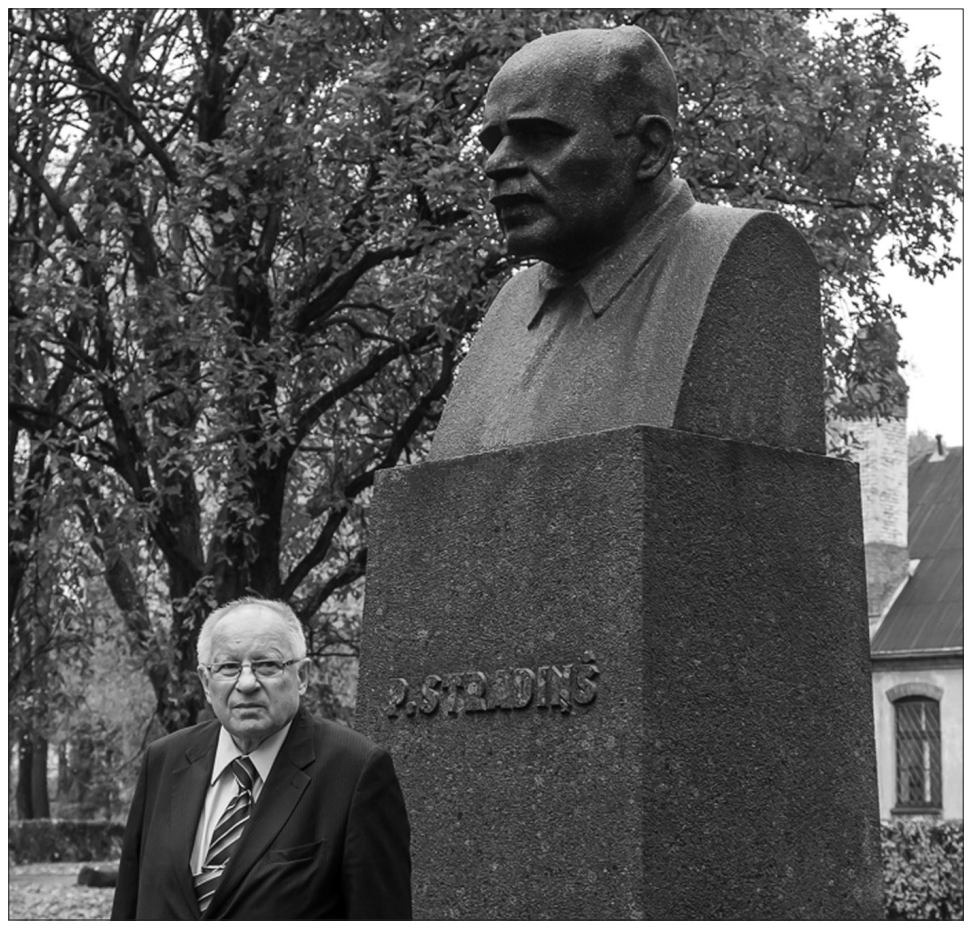

Akadēmiķis Jānis Stradiṇš slimnīcas teritorijā pie profesora Paula Stradiņa pieminekḷa 2013. gada oktobrī 
Aleksandra Briede pateicībā par vīra ārstēšanu arī izveidoja savu metu P. Stradiņa piemineklim, bet to neiesniedza konkursam. Tomēr ārsti pierunāja viņu, un A. Briedes iecere uzvarēja. Pārējie konkursanti pat bija apvainojušies...

1958. gada augustā bija LPSR Ministru padomes lēmums par Paula Stradiņa piemiņas iemūžināšanu, un 1963. gada 11. jūnijā slimnīcā P. Stradiṇa krūšutēlu uzstādīja, to atklāja vēlākais Saeimas deputāts profesors Viktors Dinevičs, toreiz - Rīgas pilsētas L,eņina rajona izpildkomitejas priekšsēdētājs. Tas notika diezgan ātri, lai gan t. s. Arvīda Pelšes laikā sevišķi nesteidzās. Sākumā pieminekli vēejējās uzstādīt skvēriṇā ārpus slimnīcas.

Lai gan P. Stradiņš nebija ne lielīgs, ne lielman̄̄gs, taču viņš savas dzīves laikā vēl paguva pateikt: "Ziniet, es gan negribētu, lai man pieminekli celtu ārpus slimnīcas, kur tie dzērāji sēž un kur visi viņu var apgānīt.” Tur tiešām pulcējās dzērāji. Jānis Stradiņš atminējās: "Un tas man nedaudz tā "grieza”, ka viņš runā par pieminekli, jo neviens jau vēl netaisījās tādu celt.” Bet Pauls Stradiņš tomēr apzinājās savu vērtību, zināja, kāda tā bija.

Saglabājusies fotogrāfija, kas ataino medicīnas māsu goda ceḷu, izvadot Paulu Stradiņu no morga uz mājām.

Tomēr jāatzīst, ja tolaik nebūtu nacionālkomunistu - Eduarda Berklava, Viḷa Krūmiņa un Kārḷa Ozoliņa -, tad ne slimnīcu būtu nosaukuši P. Stradiṇa vārdā, ne ar̄̄ pieminekli būtu cēluši, varbūt arī muzejs nebūtu dibināts kāa valsts iestāde. Taču viss risinājās īstajā brīdī. 1961. gada septembrī Rīgā, Antonijas ielā 1, tika atklāts Paula Stradiṇa Medicīnas vēstures muzejs, un tā turpmākā vēsture saistās jau ar citu laiku un citu vietu.

Jānis Stradiñ̌, Dr. habil. chem., Dr. hist. h. c., akadēmiķis

Latvijas Zinātṇu akadēmija

stradins@1za.lv

Juris Salaks, Dr. med, profesors

Rīgas Stradiṇa universitāte

juris.salaks@rsu.lv

Rita Grāvere, Dr. hist.

Paula Stradiña Medicīnas vēstures muzejs

rita_gravere@inbox.lv 